\title{
Analysis of a hypothetical Tobacco Plain Packaging legislation in Peru under the Test of Proportionality applied by the Peruvian Constitutional Court
}

SOLORZANO, RAUL R.

Pontificia Universidad Católica del Perú (Pontifical Catholic University of Peru)

Abstract

In the context of compliance with the World Health Organization Framework Convention on Tobacco Control, Australia was the first country in the world to implement, in December 2012, legislation on Tobacco Plain Packaging (TPP).

Through this research, we will analyze what could happen in Peru if eventually a TPP legislation is adopted, using the perspective of the Test of Proportionality applied by the Peruvian Constitutional Court.

This study has been divided into three sections: constitutional rights involved in the TPP restriction; characteristics of the TPP legislation; and the analysis of the TPP under the Test of Proportionality.

Research for this paper was funded by the Swiss Secretariat for Economic Affairs (SECO) under a partnership agreement with the World Trade Institute of the University of Bern, Switzerland.

Disclaimer: These papers have not been formally edited. Citations should refer to a "SECO Working Paper", with appropriate reference made to the author(s). 


\title{
"Analysis of a hypothetical Tobacco Plain Packaging legislation in Peru under the Test of Proportionality applied by the Peruvian Constitutional Court"
}

\author{
Raúl R. Solórzano ${ }^{1}$
}

\section{INTRODUCTION}

According to the World Health Organization, tobacco kills nearly 6 million people each year. This organization points out that more than 5 million of those deaths are the result of direct tobacco use while more than 600,000 are the result of non-smokers being exposed to second-hand smoke ${ }^{2}$.

In view of the above, in recent years governments around the world, in the context of compliance with the World Health Organization Framework Convention on Tobacco Control (hereinafter WHO FCTC), have been introducing in their legislations a variety of restrictive measures such as advertising bans, images and health warnings on packaging, etc.

Australia has been one of the countries that has worked in this regard. It became, in November 2011, the first country in the world to legislate on Tobacco Plain Packaging (hereinafter TPP). Against this measure, British American Tobacco, Japan Tobacco International, Phillip Morris Ltd and Imperial Tobacco challenged the plain packaging legislation in the High Court of Australia. This legal process ended in August 2012 with the anticipated ruling of the High Court, by which the TPP legislation was declared constitutionally valid and was implemented, as scheduled, in December 2012.

These days, after the approval of the Australian TPP legislation, other countries are evaluating the possibility of introducing similar regulations. Consequently, through this research, we will assess what could happen in Peru if eventually a TPP (identical to the Australian legislation) is adopted, using only the perspective of the Peruvian Constitutional Court.

In order to achieve this objective, our research has been divided into three sections. First, the constitutional rights involved will be analyzed. Subsequently, the particularities of the TPP will be detailed and, thirdly, the hypothetical legislation will be analyzed according to the Test of Proportionality applied by the Peruvian Constitutional Court.

\section{CONSTITUTIONAL RIGHTS INVOLVED IN A TPP LEGISLATION}

\footnotetext{
${ }^{1}$ Master of Laws, with mention in Intellectual Property and Competition Law, Pontificia Universidad Católica del Perú (PUCP). Lawyer (PUCP). Professor of the Faculty of Law at PUCP. The author expresses his special gratitude to Javier Murillo and Angela Casafranca, research assistants for this work. Email: solorzano.rr@pucp.pe
}

${ }^{2}$ Source: http://www.who.int/mediacentre/factsheets/fs339/en/ 
Our Constitution is the principal norm applied in Peru. It has policies and principles that are the base of the Peruvian legal system.

\section{a) Freedom of private initiative}

Article 58 of the 1993 Constitution states that freedom of private initiative is carried out under a regime of social market economy. In this regard, Marcial Rubio indicates that "free private enterprise is a constitutional right established (...) and it means that people are free to conduct economic activities they consider best to obtain the resources of their daily life and capitalization"3.

It should be added that, although individuals are not prohibited from any aspect of economic activity, this does not mean that the State renounces to supervise economic process. That is why we do not follow a completely liberal economic model but one that also takes into consideration a social aspect. Similarly, there are previous steps that individuals should take before conducting economic activities.

\section{b) Freedom of enterprise, trade and industry}

This right, closely related to the previous one is mentioned in Article 59 of the Constitution ${ }^{4}$. Indeed, freedom of private initiative includes freedom of enterprise, trade and industry. Under this mandate, people are free to carry out their business and trade according to their interests, while always respecting morals, health and public safety ${ }^{5}$. About the limits or conditions of the exercise of freedom of enterprise, Baldo Kresalja and César Ochoa note that "these act for the benefit of other constitutional interests that often are opposed to the subjective rights of economic operators or entrepreneurs competing with each other"6. Precisely because of public health the State can impose certain restrictions related to packaging, trading and advertising of tobacco.

It should also be added that, according to Gaspar Ariño ${ }^{7}$, the essential content of freedom of enterprise comprises:

i. Freedom of company creation and freedom of market access.

ii. Freedom of organization or the right to the company.

iii. Freedom of management of the company.

\footnotetext{
${ }^{3}$ RUBIO CORREA, Marcial. Estudio de la Constitución Política de 1993. Lima: Fondo Editorial de la PUCP. 1999. Vol. III. p. 199.

${ }^{4}$ Constitution of 1993. Article 59.- "The State promotes wealth creation and guarantees the freedom to work, as well as freedom of enterprise, trade and industry. Exercising these freedoms must not be harmful to the public morals, health or safety. The State promotes those sectors suffering from unequal opportunities for advancement. In that sense, it promotes small businesses of all types."

${ }^{5}$ RUBIO CORREA, Marcial. Op cit. p. 227-228

${ }^{6}$ KRESALJA, Baldo and César OCHOA. Derecho Constitucional Económico. Lima: Fondo Editorial de la PUCP. 2009. p. 460.
}

7 ARIÑO ORTIZ, Gaspar. Principios constitucionales de la libertad de empresa: libertad de comercio e intervencionismo administrativo. Madrid: Marcial Pons, 1995. p. 260. 


\section{c) Freedom of expression}

The right to freedom of expression, mentioned in Article 2, paragraph 4 of the Constitution ${ }^{8}$ does not specifically refer to economic manifestations such as advertising. Initially, doctrine and jurisprudence did not consider advertising as an aspect of freedom of expression, limiting this right to the protection of opinions and information.

The previous posture, known in the United States as the Commercial Speech Doctrine, was abandoned in 1976 through the Virginia State Board of Pharmacy vs. Virginia Citizens Consumer Council case, which established that economic interests could be protected, integrating advertising within freedom of expression $^{9}$. In Europe, commercial advertising was not considered part of freedom of expression until the 1990s with the case "Pablo Casado Coca", by which the European Court of Human Rights stated that freedom of expression of Mr. Casado had been affected by not allowing him to advertise. On this issue, we consider that it is necessary to note that the advertising of some goods and services with particular characteristics may be subject to certain limits.

We agree with Antoni Rubí when he points out that advertising and other forms of commercial communication made by entrepreneurs in the market are expression and, on some occasions, information, promoting the functions normally associated to freedom of expression ${ }^{10}$.

\section{d) Property right}

According to Article 70 of the Peruvian Constitution, the property right is inviolable and the State guarantees it. The property right is exercised in line with the common good and within the limits of the law. The Constitution adds that no one may be deprived of his property except, exclusively, due to national security or public necessity declared by law, and upon payment of compensation for possible damage.

In this regard, Abraham García notes that "property rights, among other approaches, can be understood as a subjective legal situation, constitutionally protected, which owns all subject of law. Through this law, the proprietor is entitled to use all the attributes of the good which he owns; in other words, is

\footnotetext{
${ }^{8}$ Constitution of 1993. Article 2.- "Every person has the right:

(...)

4. to freedom of information, opinion, expression and dissemination of thought either orally, or in writing or by images, by any means of social communication whatsoever, and without previous authorization, censorship or impediment in accordance with the law. (...)"

${ }^{9}$ KEMELMAJER DE CARLUCCI, Aída. La Publicidad y los consumidores en el fin de siglo. Gaceta Jurídica - Actualidad Jurídica, Vol. 60, 1998. p. 71 A-72-A.

${ }^{10}$ RUBÍ, Antoni. Publicidad Comercial y Libertad de Expresión. La protección constitucional de la información en el mercado. Doctoral Thesis. Pompeu Fabra University. 2007. p. 407.
} 
entitled to use it, enjoy it, claim it against dispossession, transfer it and exclude from such use to whom is not the owner"11.

While normally the property includes movable and immovable goods, property right is not absolute because it is exercised in harmony with the common good, making it possible to take actions based on social interest or on other causes of general interest, whose purpose is the common good, which thus becomes the foundation of property ${ }^{12}$.

The Peruvian Constitutional Court, through fundament 26 of Sentence No. 0008-2003-AI/TC, has established that the right of property "is conceived as the legal power allowing a person to use, enjoy, dispose and claim a good. Thus, the owner may directly use the good, receive benefits and products, and give interests the appropriate destination or condition, always performing those activities in harmony with the common good and within the limits established by the law and even be able to recover it if someone has unlawfully taken it".

At this point, it should be added that the expropriation is the maximum limitation of property rights, which consists of the acquisition by the State of private property ownership.

About the particular form of indirect or regulatory expropriation, we agree with Günther Gonzales ${ }^{13}$ when he mentions that this is not caused by the sole limitation of essential faculties, but by the deprivation of all enjoyment, with which the good does not produce any profit.

\section{e) Freedom of intellectual creation and property on such creations}

According to paragraph 8 of Article 2 of the Peruvian Constitution, every person has the right to freedom of intellectual, artistic, technical and scientific creation, as well as to ownership of such creation and to any benefit derived from it. The State promotes access to culture and fosters its development and diffusion. It should be noted that the Constitution, upon recognizing the right of property of creations, refers to Intellectual Property rights, which include both Industrial Property rights (trademarks and patents in general) and Copyright (works).

As an object of this research is to analyze the restrictions on the trademark rights of the tobacco industry, we consider that it is important to develop below some key aspects of trademark law in Peru.

In a context of social market economy, trademarks, as Industrial Property elements, are of great importance because they allow us to differentiate the

\footnotetext{
${ }^{11}$ GARCÍA, Abraham. La protección constitucional del derecho de propiedad. Alcances sobre sus contenidos esencial y constitucional. In: PRIORI, Giovanni (Ed.) Estudios sobre propiedad. Lima: Fondo Editorial de la PUCP, 2012. p. 315.

${ }^{12}$ GONZALES, Günther. Artículo 70. Derecho de propiedad y expropiación. In: GUTIÉRREZ, Walter (Dir.) La Constitución comentada. Lima: Gaceta Jurídica, 2013. Vol. II. p. 202.

${ }^{13}$ Ibid. p. 240
} 
various products and services offered to consumers. In this regard, Carlos Fernández-Novoa claims that "the sign associated to the products by the entrepreneur becomes a true trademark when contemplating the sign unleashes - in the consumers' minds - representations around the commercial origin, quality and, if applicable, good reputation of the products previously referred to" ${ }^{14}$.

According to the Registration Principle of trademarks in Peru, we follow an attributive or constitutive right acquisition system. Therefore, trademark ownership is obtained through its registration with the Distinctive Sign Direction of the National Institute for the Defense of Competition and Protection of Intellectual Property (INDECOPI). This is by virtue of Article 154 of Decision 486 indicating that "the right to exclusive use of a trademark is acquired by its registration with the competent national office".

Trademarks represent intangible assets through which products and services in the market are identified and differentiated, denoting a particular commercial origin. Being an intangible asset, the brand always requires an externalization means called corpus mechanicum, unlike mysticum corpus which consists of the very idea of the sign. On this specific topic, Baldo Kresalja mentions that "the intangible asset requires externalization because while intellectual creation is retained in the mind, it cannot be considered objectively, as opposed to the act it is supported by, remaining in the subject's privacy." 15

Article 134 of Decision 486 states that any sign that is capable of distinguishing goods and services on the market shall constitute a trademark. Signs that are capable of graphic representation shall be eligible for registration as trademarks. The nature of the goods or services to which a trademark is to be applied shall in no case form an obstacle to the registration of the trademark. This article adds that the following signs, among others, shall be capable of constituting a trademark:

a) Words or a combination of words.

b) Pictures, figures, symbols, graphic elements, logotypes, monograms, portraits, labels, and emblems.

c) Sounds and smells.

d) Letters and numbers.

e) A color demarcated to give it a specific shape, or a combination of colors.

f) The shape of a product its packaging or wrappings.

g) Any combination of the signs or means indicated in the items above.

With respect to the functions of the trademarks, from the several authors addressing this issue ${ }^{16}$, we consider that the following four functions, set out by Carlos Fernández-Novoa, are the most appropriate:

\footnotetext{
14 FERNÁNDEZ-NÓVOA, Carlos. Tratado sobre Derecho de Marcas. 2da. Ed. Madrid: Marcial Pons, 2004. p. 30

15 KRESALJA, Baldo: Bienes Inmateriales y Derechos Intelectuales. In: Gaceta Jurídica Especial Propiedad Industrial. Vol. 48. Lima, 1997. p. 5.

${ }^{16}$ OTAMENDI, Jorge. Derecho de marcas. 6ta. Ed. Buenos Aires: Lexis Nexis, 2006. p. 2-5. BERCOVITZ, Alberto. Apuntes de Derecho Mercantil. 10ma. Ed. Navarra: Aranzadi, 2009. p.
} 
1. Function indicating commercial origin. This is the main function of the trademark because it indicates the commercial origin for products and services, differentiating them from others existing in the market.

2. Function indicating quality. Considering that the trademark also provides us information, consumers estimate that products or services identified by the same trademark have consistent quality, regardless of the place of purchase. In this regard, Jorge Otamendi says that "it is the interest of the trademark owner that the product maintains uniform quality and that the consumer is not frustrated when choosing that trademark again. A product or service that worsens its quality will surely lose consumers and can lead the trademark to disappear from the market." ${ }^{17}$.

3. Function condensing possible goodwill or reputation. The trademark owner wants his/her sign, throughout time, to obtain fame, reputation or goodwill among consumers. For that, many resources must be invested and the quality of products or services identified by a trademark must be improved, along with powerful advertising campaigns. According to William Landes and Richard Posner, "once the reputation is created, the company will get better gains because repeated purchases and referrals will generate more sales, and because consumers will be willing to pay higher prices in exchange for lower search costs and greater security in obtaining consistent quality"18.

4. Advertising function of the trademark. Advertising is any form of public communication through which the trademark owners try to promote, among consumers, the purchase of a product or a service. Thus, the trademark itself plays a fundamental role because, in many cases, it can convince, by itself, consumers to purchase a particular good or service.

\section{f) Right to health}

Article 7 of the Peruvian Constitution states that everyone has the right to protect his health, family environment and community, and the duty to contribute to their advocacy. Article 9 mentions that the State determines national health policy, having the responsibility of designing and monitoring its implementation. In this regard, the Peruvian Constitutional Court, through Sentence No. 2064-2004-AA/TC, stated that "the right to health, under Article 7 of the 1993 Constitution, includes not only the right to personal health, but also access to minimum sanitary conditions in order to live a dignified life. Thus, it is stated that the right to health includes, first, to timely and appropriate health care, and secondly, the factors that determine good health, such as clean water, nutrition, housing and environmental and occupational health conditions, among others".

\footnotetext{
499-500. McCARTHY, Thomas. McCarthy on Brands and Unfair Competition. 3ra. Ed. New York: Clark Boardman Callaghan, 1994. Chapter 3 (The Functions of Brands)

${ }^{17}$ OTAMENDI, Jorge. Op. cit. p. 4.

${ }^{18}$ LANDES, William and Richard POSNER. El contenido económico del Derecho de Marcas. In: lus et Veritas No. 13, Lima, 1996. p. 75.
} 
Elena Alvites indicates that it is the duty of the State to adopt a national health policy that derives from the recognition of the fundamental right to health, with the aim to facilitate equitable access of all people to health services ${ }^{19}$.

Also, the Peruvian Constitutional Court, through Sentence No. No. 00032-2010$\mathrm{PI} / \mathrm{TC}$, mentioned that "the aim of protecting the health of consumers of tobacco and of reducing healthcare costs generated by the treatment of tobacco diseases, is constitutionally valid. Additionally (...) reducing the consumption of tobacco in order to protect the health of smokers, is not only a constitutionally permissible aim, but it is a constitutionally mandatory purpose since Peru ratified the World Health Organization Framework Convention on Tobacco Control".

\section{ANALISYS OF AUSTRALIAN TOBACCO PLAIN PACKAGING LEGISLATION}

It is important to mention that the objects of the Australian Tobacco Plain Packaging Act 2011 are:

1. To improve public health by:

1.1 Discouraging people from taking up smoking, or using tobacco products.

1.2 Encouraging people to give up smoking, and to stop using tobacco products.

1.3 Discouraging people who have given up smoking, or who have stopped using tobacco products, from relapsing.

1.4 Reducing people's exposure to smoke from tobacco products.

2. To give effect to certain obligations that Australia has as a party to the Convention on Tobacco Control.

3. To contribute to achieving the above mentioned objects by regulating the retail packaging and appearance of tobacco products in order to:

3.1 Reduce the appeal of tobacco products to consumers.

3.2 Increase the effectiveness of health warnings on the retail packaging of tobacco products.

3.3 Reduce the ability of the retail packaging of tobacco products to mislead consumers about the harmful effects of smoking or using tobacco products.

The following are a compilation of the most important dispositions of the Australian Tobacco Plain Packaging Act 2011, Tobacco Plain Packaging Regulations 2011 and Tobacco Plain Packaging Amendment Regulations $2012^{20}$ :

\footnotetext{
${ }^{19}$ ALVITES, Elena. Articulo 9. Política nacional de salud. In: GUTIÉRREZ, Walter (Dir.) La Constitución comentada. Lima: Gaceta Jurídica, 2013. Vol. I. p. 576-577.

${ }^{20}$ Source: http://www.comlaw.gov.au/Details/C2013C00190 and http://www.comlaw.gov.au/Details/F2013C00801
} 
1. The outer surfaces and inner surfaces of the retail packaging must not have any decorative ridges, embossing, bulges or other irregularities of shape or texture, or any other embellishments.

2. Any glues or other adhesives used in manufacturing the retail packaging must be transparent and not coloured.

3. The cigarette pack or carton must be rigid and made of cardboard.

4. When the cigarette pack or carton is closed, each outer surface must be rectangular and the surfaces must meet at firm 90 degree angles.

5. All edges of the cigarette pack or carton must be rigid, straight and not rounded, bevelled or otherwise shaped or embellished in any way.

6. The dimensions of a cigarette pack, when the flip-top lid is closed, must not be:

a) Height: less than $85 \mathrm{~mm}$ or more than $125 \mathrm{~mm}$.

b) Width: less than $55 \mathrm{~mm}$ or more than $82 \mathrm{~mm}$.

c) Depth: less than $20 \mathrm{~mm}$ or more than $42 \mathrm{~mm}$.

7. The only opening to the cigarette pack must be a flip-top lid which must be hinged only at the back of the pack and have straight edges.

8. The inside lip of the cigarette pack must have straight edges, other than corners which may be rounded, and neither the lip, nor the edges of the lip, may be bevelled or otherwise shaped or embellished in any way.

9. If the cigarette pack contains lining, the lining of the pack must be made only of foil backed with paper. The lining of a cigarette pack must be silver coloured foil with a white paper backing.

10. All outer surfaces and inner surfaces of the retail packaging must have a matt finish and be drab dark brown (colour known as Pantone 448C).

11. Any brand, business or company name, or any variant name, for tobacco products that appears on the retail packaging of those products must not appear more than once on any of the following outer surfaces of the pack or carton, according to the following table:

\begin{tabular}{|c|c|c|}
\hline If this name: & $\begin{array}{l}\text { appears on this } \\
\text { surface: }\end{array}$ & Then, the name: \\
\hline $\begin{array}{l}\text { a brand, business or } \\
\text { company name }\end{array}$ & $\begin{array}{l}\text { the front outer } \\
\text { surface of a } \\
\text { cigarette pack }\end{array}$ & $\begin{array}{l}\text { must appear: } \\
\text { a) horizontally below, and in the } \\
\text { same orientation as, the health } \\
\text { warning; and } \\
\text { b) in the centre of the space } \\
\text { remaining on the front outer } \\
\text { surface beneath the health } \\
\text { warning. }\end{array}$ \\
\hline $\begin{array}{l}\text { a brand, business or } \\
\text { company name }\end{array}$ & $\begin{array}{l}\text { the front outer } \\
\text { surface of a } \\
\text { cigarette carton }\end{array}$ & $\begin{array}{l}\text { must appear: } \\
\text { a) in the same orientation as the } \\
\text { health warning; and } \\
\text { b) in the centre of the space on } \\
\text { the front outer surface that is } \\
\text { not occupied by the health } \\
\text { warning. }\end{array}$ \\
\hline $\begin{array}{l}\text { a brand, business or } \\
\text { company name }\end{array}$ & $\begin{array}{l}\text { any } \\
\text { surface outer } \\
\text { cigarette pack or } \\
\text { cigarette carton } \\
\text { (other than a } \\
\text { front outer }\end{array}$ & $\begin{array}{l}\text { must appear: } \\
\text { a) horizontally; and } \\
\text { b) in the centre of the outer } \\
\text { surface of the pack or carton. }\end{array}$ \\
\hline
\end{tabular}




\begin{tabular}{|c|c|c|}
\hline If this name: & $\begin{array}{l}\text { appears on this } \\
\text { surface: }\end{array}$ & Then, the name: \\
\hline & surface) & \\
\hline variant name & $\begin{array}{l}\text { any outer } \\
\text { surface of a } \\
\text { cigarette pack or } \\
\text { cigarette carton }\end{array}$ & $\begin{array}{l}\text { must appear: } \\
\text { a) horizontally and immediately } \\
\text { below the brand, business or } \\
\text { company name; and } \\
\text { b) in the same orientation as the } \\
\text { brand, business or company } \\
\text { name. }\end{array}$ \\
\hline
\end{tabular}

12. Any brand, business or company name, or any variant name, appearing on cigarette packs or cigarette cartons must be printed:

a) In the typeface known as Lucida Sans.

b) For a brand, business or company name - no larger than 14 points in size.

c) For a variant name - no larger than 10 points in size.

d) With the first letter in each word capitalised and with no other upper case letters.

e) In a normal weighted regular font.

f) In the colour known as Pantone Cool Gray 2C.

13. The retail packaging of tobacco products must not have any inserts or onserts.

14. No part of the retail packaging of tobacco products may make a noise, or contain or produce a scent that could be taken to constitute tobacco advertising and promotion.

15. The retail packaging of tobacco products must not include any features designed to change the packaging after retail sale, including (without limitation) heat activated inks, inks or embellishments designed to appear gradually over time, inks that appear fluorescent in certain light, panels designed to be scratched or rubbed to reveal an image or text, removable tabs, fold-out panels.

16. The paper casing, and lowered permeability band (if any), of cigarettes must be white or white with an imitation cork tip.

17. A cigarette may be marked with an alphanumeric code. If a cigarette includes a filter tip, the filter tip must be white.

Following the above provisions, the final designs of the packaging would be as shown below: 

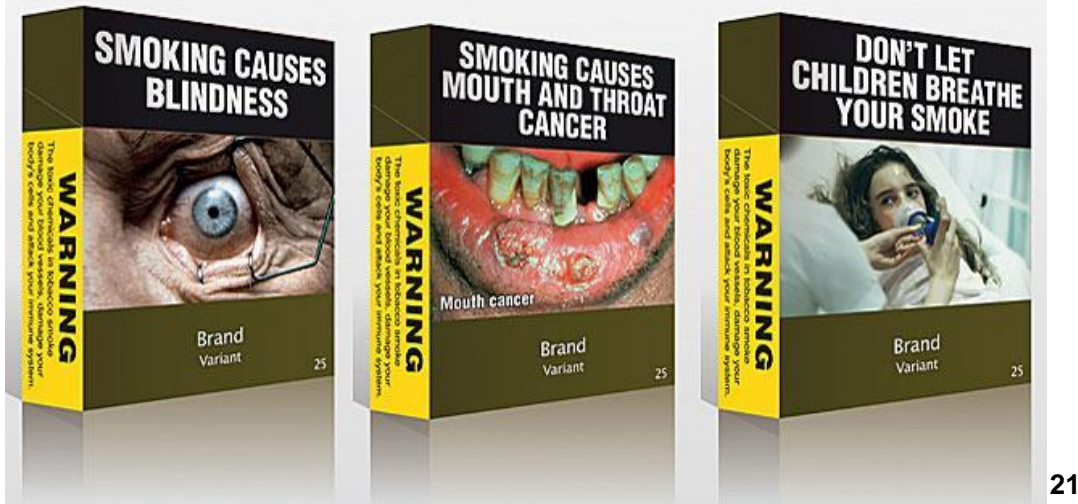

According to the dispositions of the Australian TPP, only "word trademarks" could be used. Consequently, the use of the following types of trademarks is prohibited:

1. Figurative trademarks: signs made exclusively of a graphic or figure.

2. Mixed trademarks: made of a word part and a figurative part.

3. Three-dimensional trademarks: made of product forms, packaging or wrappings.

4. Trademarks made of a form-delimited color: for example, the red color inside a triangle.

5. Trademarks made of a color combination: like the previous case, if the colors are inside forms containing them.

6. Animated trademarks: those made of moving images.

7. Sound trademarks: made of a melody or a sound identifying a particular product or service.

8. Taste, smell and tactile trademarks: they can be registered as long as they are distinctive and meet the graphic representation requirement.

Currently in Peru, the packaging of tobacco cigarettes is traded as follows:
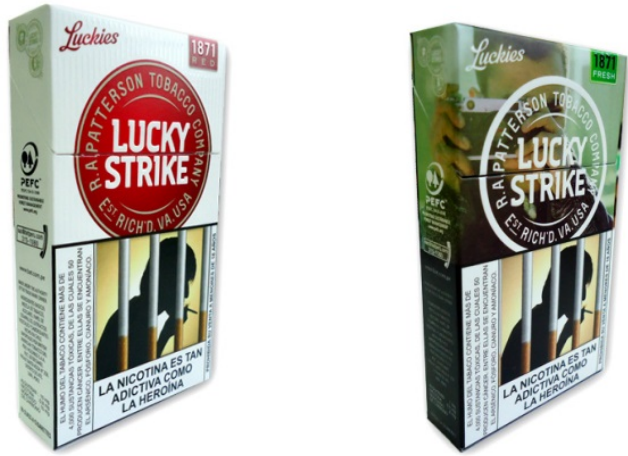

Additionally, some of the existing official Trademark Registrations in Peru are:

\footnotetext{
${ }^{21}$ Source: http://www.tobaccotactics.org/index.php/File:Australian_packs.JPG
} 


\begin{tabular}{|c|c|}
\hline Class 34, Registration No. & $\begin{array}{c}\text { Class 34, Registration No. } \\
160547\end{array}$ \\
\hline $\begin{array}{c}\text { CमMEL } \\
\text { Class 34, Registration No. } \\
150349\end{array}$ & $\begin{array}{c}\text { Class 34, Registration No. } \\
168168\end{array}$ \\
\hline $\begin{array}{c}\text { Class 34, Registration No. } \\
98596\end{array}$ & $\begin{array}{c}\text { Class } 34, \text { Registration No. } \\
103388\end{array}$ \\
\hline Class 34, Registration No. & $\begin{array}{c}\text { Class 34, Registration No. } \\
120328 \\
\text { C. }\end{array}$ \\
\hline
\end{tabular}




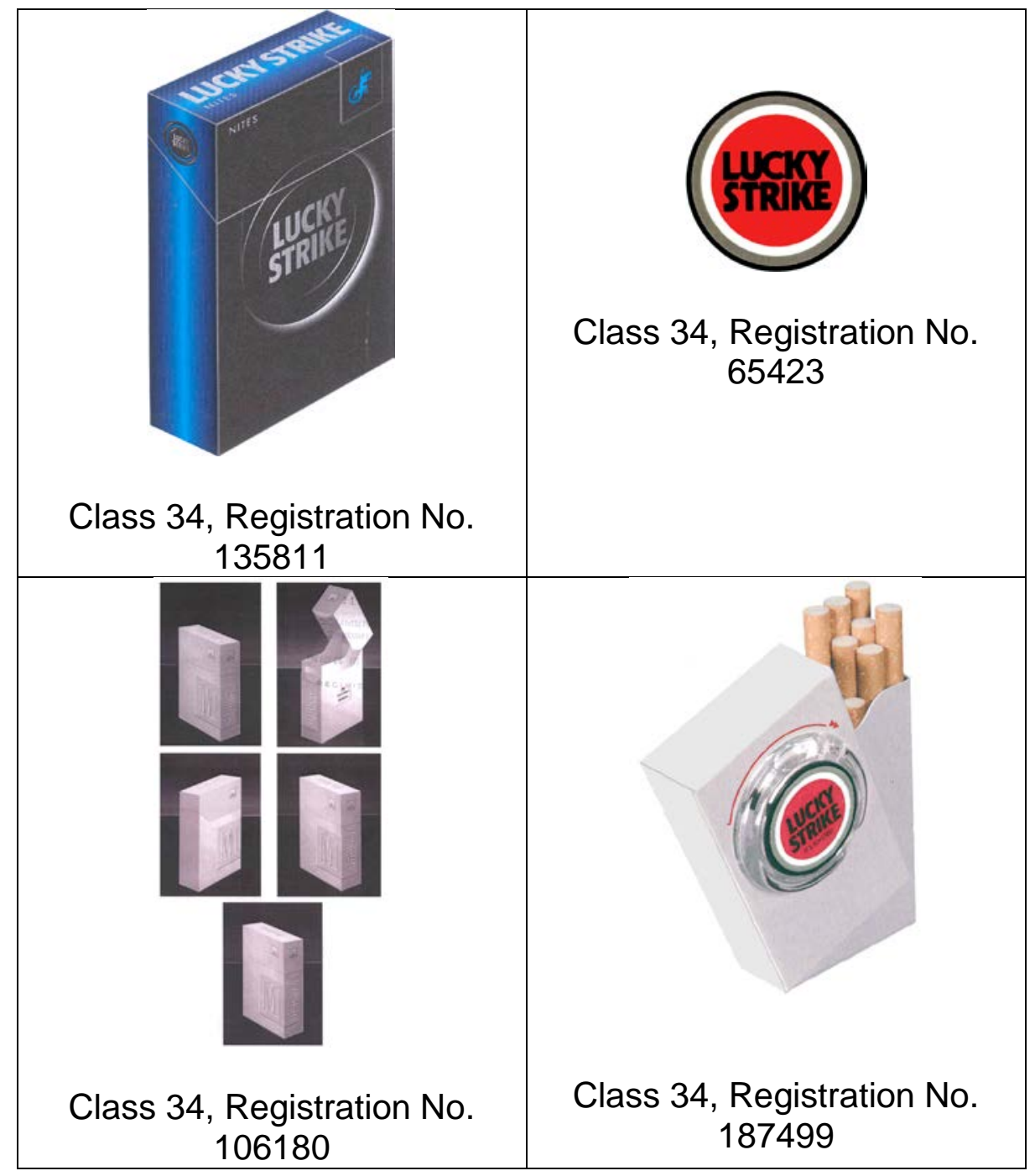

According to what would be established in Peru with an eventual TPP, any of the cited trademark registrations could be used.

\section{TEST OF PROPORTIONALITY APPLIED BY THE PERUVIAN CONSTITUTIONAL COURT}

In this section, we will analyze the hypothetical introduction of a PPT in Peru. In this kind of situation, if the tobacco industry decides to file a Demand of Unconstitutionality (on the basis of its restricted constitutional rights) against the PPT legislation, the Peruvian Constitutional Court would apply the Test of Proportionality, through the following three sub-principles:

- Sub-principle of suitability or adequacy.

- Sub-principle of necessity.

- Sub-principle of proportionality strictu sensu.

However, before the analysis of the three sub-principles, we have to make the verification of a constitutionally legitimate purpose. 
The norm or limiting measure must provide a constitutionally legitimate purpose as the basis for interference in other principle. If there is no purpose, the measure is unconstitutional. Therefore, we must find the specific measure, the specific purpose (immediate purpose) and the satisfied fundamental principle (mediate purpose).

\section{a) The specific measure: a TPP in Peru}

The legislative restriction to tobacco industry companies has different forms. However, it will be very helpful to see the context where the Plain Packaging Policy lies in order to establish the characteristics of the measure. In this respect, we can verify three types of measures based on the provisions of the WHO FCTC and the subsequent adaptations of the parties:

\begin{tabular}{|l|l|lr|}
\hline \multicolumn{1}{|c|}{ First stage } & \multicolumn{1}{|c|}{ Second stage } & \multicolumn{1}{c|}{ Third stage } \\
\hline Ban of the advertising & Absolute ban of the & Tobacco Plain \\
of tobacco products in & advertising of tobacco & Packaging measures. \\
radio and television & products in all and any & Based mainly on \\
media. Based mainly & kind of media. Based & Article 11 of the \\
on Article 13 of the & mainly on Article 13 of the & WHO FCTC \\
WHO FCTC & & \\
\hline
\end{tabular}

\footnotetext{
${ }^{22}$ Article 13 of the WHO FCTC - Tobacco advertising, promotion and sponsorship:

"1. Parties recognize that a comprehensive ban on advertising, promotion and sponsorship would reduce the consumption of tobacco products.

2. Each Party shall, in accordance with its constitution or constitutional principles, undertake a comprehensive ban on all tobacco advertising, promotion and sponsorship. This shall include, subject to the legal environment and technical means available to that Party, a comprehensive ban on cross-border advertising, promotion and sponsorship originating from its territory. In this respect, within the period of five years after entry into force of this Convention for that Party, each Party shall undertake appropriate legislative, executive, administrative and/or other measures and report accordingly in conformity with Article 21.

3. A Party that is not in a position to undertake a comprehensive ban due to its constitution or constitutional principles shall apply restrictions on all tobacco advertising, promotion and sponsorship. This shall include, subject to the legal environment and technical means available to that Party, restrictions or a comprehensive ban on advertising, promotion and sponsorship originating from its territory with cross-border effects. In this respect, each Party shall undertake appropriate legislative, executive, administrative and/or other measures and report accordingly in conformity with Article 21.
}

4. As a minimum, and in accordance with its constitution or constitutional principles, each Party shall:

(a) prohibit all forms of tobacco advertising, promotion and sponsorship that promote a tobacco product by any means that are false, misleading or deceptive or likely to create an erroneous impression about its characteristics, health effects, hazards or emissions;

(b) require that health or other appropriate warnings or messages accompany all tobacco advertising and, as appropriate, promotion and sponsorship;

(c) restrict the use of direct or indirect incentives that encourage the purchase of tobacco products by the public;

(d) require, if it does not have a comprehensive ban, the disclosure to relevant governmental authorities of expenditures by the tobacco industry on advertising, promotion and sponsorship not yet prohibited. Those authorities may decide to make those figures available, subject to national law, to the public and to the Conference of the Parties, pursuant to Article 21;

(e) undertake a comprehensive ban or, in the case of a Party that is not in a position to undertake a comprehensive ban due to its constitution or constitutional principles, restrict 
We can appreciate that the three measures, including the TPP, are derived from the objective of article 3 of the WHO CFTC, which is to protect present and future generations from the devastating health, social, environmental and economic consequences of tobacco consumption and exposure to tobacco smoke by providing a framework for tobacco control measures to be implemented by the Parties at the national, regional and international levels to reduce the prevalence of tobacco use and exposure to its smoke.

\section{b) The specific purpose (immediate purpose)}

tobacco advertising, promotion and sponsorship on radio, television, print media and, as appropriate, other media, such as the internet, within a period of five years; and

(f) prohibit, or in the case of a Party that is not in a position to prohibit due to its constitution or constitutional principles restrict, tobacco sponsorship of international events, activities and/or participants therein.

5. Parties are encouraged to implement measures beyond the obligations set out in paragraph 4.

6. Parties shall cooperate in the development of technologies and other means necessary to facilitate the elimination of cross-border advertising.

7. Parties which have a ban on certain forms of tobacco advertising, promotion and sponsorship have the sovereign right to ban those forms of cross-border tobacco advertising, promotion and sponsorship entering their territory and to impose equal penalties as those applicable to domestic advertising, promotion and sponsorship originating from their territory in accordance with their national law. This paragraph does not endorse or approve of any particular penalty.

8. Parties shall consider the elaboration of a protocol setting out appropriate measures that require international collaboration for a comprehensive ban on cross-border advertising, promotion and sponsorship."

\section{${ }^{23}$ Article 11 of the WHO FCTC - Packaging and labelling of tobacco products:}

"1. Each Party shall, within a period of three years after entry into force of this Convention for that Party, adopt and implement, in accordance with its national law, effective measures to ensure that:

(a) tobacco product packaging and labelling do not promote a tobacco product by any means that are false, misleading, deceptive or likely to create an erroneous impression about its characteristics, health effects, hazards or emissions, including any term, descriptor, trademark, figurative or any other sign that directly or indirectly creates the false impression that a particular tobacco product is less harmful than other tobacco products. These may include terms such as "low tar", "light", "ultra-light", or "mild"; and

(b) each unit packet and package of tobacco products and any outside packaging and labelling of such products also carry health warnings describing the harmful effects of tobacco use, and may include other appropriate messages. These warnings and messages:

(i) shall be approved by the competent national authority,

(ii) shall be rotating,

(iii) shall be large, clear, visible and legible,

(iv) should be $50 \%$ or more of the principal display areas but shall be no less than $30 \%$ of the principal display areas,

(v) may be in the form of or include pictures or pictograms.

2. Each unit packet and package of tobacco products and any outside packaging and labelling of such products shall, in addition to the warnings specified in paragraph 1(b) of this Article, contain information on relevant constituents and emissions of tobacco products as defined by national authorities.

3. Each Party shall require that the warnings and other textual information specified in paragraphs 1(b) and paragraph 2 of this Article will appear on each unit packet and package of tobacco products and any outside packaging and labelling of such products in its principal language or languages.

4. For the purposes of this Article, the term "outside packaging and labelling" in relation to tobacco products applies to any packaging and labelling used in the retail sale of the product". 
Taking into account the Australian TPP legislation, a possible TPP in Peru would have the following concrete objects:

1. Discouraging people from taking up smoking, or using tobacco products.

2. Encouraging people to give up smoking, and to stop using tobacco products.

3. Discouraging people who have given up smoking, or who have stopped using tobacco products, from relapsing.

4. Reducing people's exposure to smoke from tobacco products.

5. Reducing the appeal of tobacco products to consumers.

6. Increasing the effectiveness of health warnings on the retail packaging of tobacco products.

7. Reducing the ability of the retail packaging of tobacco products to mislead consumers about the harmful effects of smoking or using tobacco products.

\section{c) The mediate purpose}

A hypothetical TPP in Peru, based on the Australian TPP legislation, would satisfy the following fundamental principles:

1. The improvement of Public Health.

2. The compliance with obligations assumed by the Peruvian government as a party to the WHO FCTC.

In this regard, the Peruvian Constitutional Court has stated that "the realization of the constitutional and democratic State of law is only possible through the recognition and protection of fundamental rights of the people. These rights have a dual character: they are, on the one hand, subjective rights, and on the other hand, objective valuation institutions, which deserve all possible protection". ${ }^{24}$

\section{Sub-principle of suitability or adequacy}

Having identified the specific measure, the specific purpose and the mediate purpose, we must now examine whether the possible measure is appropriate or suitable to reach the constitutionally legitimate purpose

According to this first sub-principle, the Peruvian Constitutional Court, through Sentence No. 0048-2004-AI/TC, has stated that "any interference in fundamental rights must be capable or able to promote a constitutionally legitimate purpose. In other words, this sub-principle implies the constitutional legitimacy of the objective and the sufficiency of the used measure."

About the benefits of the TPP legislation, the divided opinions ${ }^{25}$ can be reflected in two different studies:

\footnotetext{
${ }^{24}$ Peruvian Constitutional Court. Sentence No. 3330-2004-AA/TC.

${ }^{25}$ We need to remember that the Australian TPP legislation is the first of its kind in the world.
} 
Firstly, we can mention the "Plain Tobacco Packaging: A Systematic Review"26, finished on 2012. A total of 37 studies were included in this review. These studies comprised 23 cross-sectional surveys, eight qualitative investigations (focus groups or interviews), four mixed methods quantitative and qualitative elements, and two intervention studies. Sixteen of the studies focussed on young people, and eight included smokers only. Most of the studies were conducted in Australasia (Australia and New Zealand), with six carried out in Canada and four in the United States. Six were run in the UK, five in France and one in Belgium. One study was from Brazil ${ }^{27}$.

With respect to the appeal of cigarettes, packs and brands ${ }^{28}$, the key findings were the following:

1. All studies reported that plain packs were rated as less attractive than branded equivalent packs, by both adults and children.

2. Plain packs were perceived to be poorer quality, poorer tasting and cheaper than branded equivalent packs.

3. Positive impressions of smoker identity and personality attributes associated with specific brands were weakened or disappeared with plain packaging.

4. Non-smokers and younger people responded more negatively to plain packs than smokers and older people.

With reference to the salience of health warnings ${ }^{29}$, the key findings were as follows:

1. Overall, the studies suggest that plain packaging tends to increase the recall of health warnings, the attention paid to them and their perceived seriousness and believability.

2. Findings appear to be moderated by the type, size and position of health warning used.

3. Only one study examined sub-group differences, and reported that nonsmokers and weekly smokers may pay more attention to warnings on plain packs than daily smokers.

In relation to the perceptions of product harm and strength ${ }^{30}$, the key findings were the following:

\footnotetext{
${ }^{26}$ MOODIE, Crawford; STEAD, Martine; BAULD, Linda; MCNEILL, Ann; ANGUS, Kathryn; HINDS, Kate; KWAN, Irene; THOMAS, James; HASTINGS, Gerard and O'MARA-EVES, Alison. (2012). Plain tobacco packaging: A systematic review. Stirling: UK Centre for Tobacco Control Studies, University of Stirling. Source:

http://phrc.Ishtm.ac.uk/papers/PHRC 006 Final Report.pdf

${ }^{27}$ Ibid. p. 24 and 84

${ }^{28}$ Ibid. p. 38

${ }^{29}$ Ibid. p. 52

${ }^{30}$ Ibid. p. 58
} 
1. Plain packaging can reduce misperceptions about the relative harmfulness of different brands.

2. Colours of packs affect perceptions of product harm and strength. In general, plain packs are perceived as more harmful than branded packs if in a darker colour such as

brown and, conversely, less harmful than branded packs if in lighter colours such as white. Red packs are perceived to contain stronger cigarettes than light-coloured packs.

3. Use of descriptors such as 'gold' or 'smooth' on plain packs have the potential to mislead consumers, as they do on branded packs.

4. In general, smokers are more likely to have misperceptions about the harmfulness of packs, both branded and plain, than non-smokers.

With regard to the smoking related attitudes, beliefs, intentions and behaviour ${ }^{31}$, the key findings were as follows:

1. Plain packs appear to increase negative feelings about smoking.

2. Plain packs are generally perceived as likely to have a deterrent effect on the onset of smoking by young people and as likely to encourage existing smokers to reduce their consumption or to quit, although in some studies they are perceived as likely to have little impact.

3. Non-smokers, lighter smokers and younger people are more likely to perceive that plain packs would discourage or reduce smoking.

According to the authors of this systematic review, the document has some strengths and limitations ${ }^{32}$. Strengths included the diversity of research methods, the diversity of samples, the different types of plain packaging evaluated and the consistency of the findings. The main limitation was that, when the study concluded, the TPP legislation had not yet entered in force in any country. Therefore it was not possible to evaluate, at that time, the impact of the policy in practice. In this point, it is important to mention that the Australian TPP legislation was implemented in December 2012.

The above mentioned review was updated in September 2013. According to the findings of 17 additional studies, it is suggested that TPP would reduce the appeal of cigarettes and smoking, enhance the salience of health warnings on packs, and address the use of packaging elements that mislead smokers about product harm ${ }^{33}$.

Secondly, we can mention the "Tobacco Packaging Regulation: an international assessment of the intended and unintended impacts" 34 , a publication written by

\footnotetext{
${ }^{31}$ Ibid. p. 68

32 Ibid. p. v

33 MOODIE, Crawford; ANGUS, Kathryn, STEAD, Martine and BAULD, Linda (2013). Plain Tobacco Packaging Research: An Update. Stirling, Scotland: Centre for Tobacco Control Research, Institute for Social Marketing, University of Stirling. p. 2. Source: http://www.stir.ac.uk/management/about/social-marketing/
}

34 DELOITTE TOUCHE TOHMATSU LIMITED (2011) Tobacco packaging regulation: an international assessment of the intended and unintended impacts. Source: 
Deloitte for British American Tobacco in May 2011. According to this study, the econometric modelling is centred on developing an understanding of the impact of pack space appropriation (PSA) regulation on licit consumption. The panel of data was constructed from 27 countries over a period of 14 years (1996$2009)^{35}$. The study concludes that:

1. There is no statistically significant direct relationship between pack space appropriation (PSA) regulation, including increasing the size of government health warnings, and licit tobacco consumption ${ }^{36}$.

2. There is consensus that TPP will reduce product differentiation and lower prices in some or all segments of the market in the short to medium term in the absence of further tax increases. TPP may also, by creating barriers to innovation, lead to an overall reduction of the breadth of products in the market ${ }^{37}$.

3. A range of commentators, including the Australian government, recognise that $\mathrm{PP}$ could lead to an increase in illicit trade ${ }^{38}$.

4. Failure to successfully defend claims that TPP infringes international trademarks rights, Intellectual Property laws and trade agreements, could result in significant legal and compensation costs for governments ${ }^{39}$.

5. Deloitte research in Australia raises concerns regarding the potential cost burden of plain packaging on small to medium sized retailers.

6. In advance of deciding to implement new forms of packaging regulation, it is suggested that governments conduct more robust research into these impact areas.

As we can see, both studies are very important due to the temporary and geographical scope taken as reference. However, they arrive at different conclusions. Considering that the first TPP in the world entered into force in Australia in December 2012, it is currently still difficult to know the impact and effectiveness of the legislation with absolute certainty. In view of this kind of situation, the Peruvian Constitutional Court has stated, through Sentence No. 008-2003-Al/TC, that in cases of reasonable doubts in the suitability of the measure, the Court presumes that the law is constitutional. Therefore, we must move to the next sub-principle under this presumption.

\section{Sub-principle of necessity}

In this stage, the restrictive measure must be examined to determine that it is the most beneficial among those that are suitable to achieve the objective. In

http://www.bat.com/group/sites/uk 9d9kcy.nsf/vwPagesWebLive/DO9DKJEB/\$FILE/medMD9

FRKWC.pdf

${ }^{35}$ Ibid. p. 4

${ }^{36} \mathrm{Ibid}$

${ }^{37}$ Ibid. p. 5

${ }^{38} \mathrm{Ibid}$.

${ }^{39}$ Ibid. p. 6 
this regard, Carlos Bernal Pulido indicates that in this comparison "it is examined whether any of the alternative means achieves two requirements: first, if it has at least the same degree of suitability as the legislative measure to contribute to achieving its immediate objective; and, secondly, if it affects negatively the fundamental right to a lesser degree. If there is an alternative means that meets these two requirements, the legislative measure must be declared unconstitutional" 40 .

According to what is mentioned in the previous sub-principle (suitability or adequacy), considering that it is presumed the constitutionality of the law, we need to examine the necessity of the measure.

Assuming a hypothetical approval of a TPP in Peru, certain types of trademark could not be used, despite having a valid Certificate of Registration issued by the competent national authority. In this regard, unlike what happens in other countries, in accordance with Article 154 of Decision 486 (Common Industrial Property Regime in the Andean Community), the right to exclusive use of a trademark is acquired by means of its registration with the competent national office. Consequently, the owner of the trademark registration obtains the exclusive faculty to use the trademark or to grant the use to a third party. On this point, the Court of Justice of the Andean Community has stated that "within the exclusivity that the registration grants to the trademark owner, there are doctrinally considered two possibilities, one positive and the other negative. For the first, the owner is allowed to use, assign or grant licenses on the trademark. The second, negative faculty, implies that the owner is entitled to prohibit (ius prohibendi) third parties to use the trademark and, accordingly, to oppose the use and registration of identical or similar trademarks." ${ }^{41}$

Considering the above, in general terms a hypothetical TPP in Peru would affect the function indicating commercial origin, which is the main function of a trademark. Indeed, under a TPP all tobacco trademarks will have to use the same position, typeface and size. This could prevent consumers from properly identifying and differentiating competing trademarks. In this regard, we agree with Alberto Alemanno and Enrico Bonadio when they state that "this fundamental function may be threatened should trademarks not be visible, or even available, to consumers when selecting a product. This is exactly what plain packaging would create, as all of the distinctive elements displayed on the box would be removed. This new measure may therefore threaten consumers' ability to make reasoned choices, as there would be little difference - besides the brand names - between the different cigarette boxes marketed by tobacco companies"42. Additionally, a TPP in Peru could also affect the function, reducing possible goodwill and the advertising function of the trademark.

\footnotetext{
40 BERNAL PULIDO, Carlos. El principio de proporcionalidad y los derechos fundamentales. Madrid: Centro de Estudios Políticos y Constitucionales. 2003. p. 736.

${ }^{41}$ Court of Justice of the Andean Community. Process 54-IP-2000.

42 ALEMANNO, Alberto and Enrico BONADIO. Plain packaging of cigarettes under EU law. Chapter in Andrew Mitchell, Tania Voon and Jonathan Liberman (Eds.) Public Health and Plain Packaging of Cigarettes: Legal Issues (Edward Elgar, UK, 2012). p. 229
} 
We consider that a hypothetical TTP in Peru would meet the requirement of necessity only in the section prohibiting the use of three-dimensional trademarks, trademarks made of a form-delimited color, trademarks made of a color combination, animated trademarks, sound trademarks and taste, smell and tactile trademarks. In this first case, the restriction is necessary and proportionate because it makes it possible to achieve a constitutionally legitimate purpose, eliminating the most attractive elements of the tobacco package. In addition, this restriction of the right of property is effected in accordance with the common good and the public health.

Nevertheless, the other section of the TPP, prohibiting the use of figurative trademarks (for example, the eagle of WINSTON) and mixed trademarks (for example LUCKY STRIKE circular logo), constitutes a measure that does not comply with the requirement of necessity. Under this modality, the main function of a trademark (indication of commercial origin) is restricted without proportionality.

Furthermore, as will be discussed below, we propose a more benign alternative means. The following table shows a graphical comparison between the use of the LUCKY STRIKE logo under a hypothetical TPP and under our proposal:

\begin{tabular}{|c|c|c|}
\hline Current packaging in & Possible packaging & Use of the trademark \\
\hline & 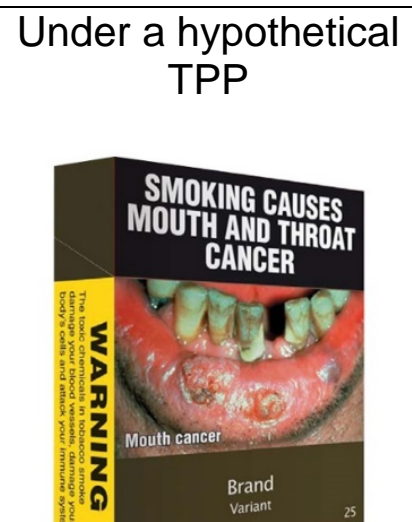 & $\begin{array}{c}\text { The use of all types of } \\
\text { trademarks is } \\
\text { prohibited, with the } \\
\text { exception of a word } \\
\text { trademark }\end{array}$ \\
\hline & $\begin{array}{c}\text { Under our proposal } \\
\text { SMOKING CQUSES } \\
\text { MOUTH AND THROAT } \\
\text { CANGER }\end{array}$ & $\begin{array}{l}\text { The use of a figurative } \\
\text { trademark or a mixed } \\
\text { trademark only is } \\
\text { allowed. For example: } \\
\text { (with predetermined } \\
\text { position and size) }\end{array}$ \\
\hline
\end{tabular}

The proposed alternative means allows only the use of figurative trademarks and mixed trademarks in a small size and specified location of the package. 
The function indicating commercial origin, which is the main function of a trademark, would have a tolerable restriction. Additionally, this alternative proposal has the same degree of suitability to achieve the constitutionally legitimate purpose and, at the same time, affects the constitutional rights of the tobacco industry (freedom of private initiative, freedom of enterprise, trade and industry, freedom of expression, property right and freedom of intellectual creation and property on such creation) to a lesser degree.

\section{Conclusion}

Since it has been found an alternative means with the characteristics described above, a hypothetical TPP legislation in Peru (based on the Australian TPP) would not comply with the sub-principle of necessity of the Test of Proportionality and therefore, according to our point of view, it would be declared unconstitutional by the Peruvian Constitutional Court. 